\title{
Pengaruh Disiplin Kerja Terhadap Kinerja Karyawan Pt Minanga Ogan Kabupaten Ogan Komering Ulu
}

\author{
Rani Anwar \\ Fakultas Ekonomi Dan Bisnis \\ Universitas Baturaja \\ e-mail: ranianwar20@gmail.com
}

\begin{abstract}
Analysis tool used in this research is doubled linear regression. The purpose of this research is to know the discipline of work either partially or simultaneously to employees' performance of PT Minanga Ogan Kabupaten Ogan Komering Ulu. The results of this study is either partially or simultaneously discipline of work influence the performance of employees of PT Minanga Ogan Kabupaten Ogan Komering Ulu. Where, coefficient t-hitung X1 (Discipline Of Work) is equal to 12,189. F-count value 676,670 and F-table value is 3.10 this means Fcount> Ftable so it can be concluded that discipline of work influence simultaneously to employees' performance at PT Minanga Ogan Kabupaten Ogan Komering Ulu.
\end{abstract}

Keywords: performance, discipline of work skills, employees

\begin{abstract}
Abstrak: Alat analisis yang digunakan dalam penelitian ini adalah regresi linier berganda. Tujuan dari penelitian ini adalah untuk mengetahui disiplin kerja baik secara parsial maupun simultan terhadap kinerja karyawan PT Minanga Ogan Kabupaten Ogan Komering Ulu. Hasil penelitian ini baik secara parsial maupun simultan kedisiplinan kerja berpengaruh terhadap kinerja karyawan PT Minanga Ogan Kabupaten Ogan Komering Ulu. Dimana koefisien t-hitung X1 (Disiplin Kerja) adalah sebesar 12,189. Nilai F hitung 676,670 dan nilai F tabel 3,10 artinya Fhitung > Ftabel sehingga dapat disimpulkan bahwa disiplin kerja berpengaruh secara simultan terhadap kinerja karyawan pada PT Minanga Ogan Kabupaten Ogan Komering Ulu.
\end{abstract}

Kata kunci: kinerja, disiplin keterampilan kerja, karyawan

\section{PENDAHULUAN}

\subsection{Latar Belakang}

Pada era globalisasi saat ini kegiatan perekonomian dunia mengalami perkembangan yang sangat pesat sehingga kemajuan yang dicapai dari segala aspek ekonomi akan diikuti oleh kemajuan sektor lain. Perubahan sektor tersebut akan membawa pengaruh didalam organisasi. Manusia merupakan unsur yang terpenting dalam suatu organisasi. Tanpa adanya peran manusia sebagai penggerak suatu organisasi tidak akan berjalan. Menurut Terry dan Rue (2014:82), yang menyatakan sebenarnya manusia adalah yang paling terdepan.
Dengan cara mengorganisir, orang-orang dipersatuka dalam pelaksanaan tugas-tugas yang saling berkaitan. Oleh karena itu, manusia merupakan penggerak dan penentu jalannya suatu organisasi.

Sumber daya manusia salah satu unsur terpenting yang dimiliki oleh perusahaan karena dalam mencapai suatu tujuan organisasi atau perusahaan . Sumber daya manusia tentunya dibutuhkan sebagai penggerak atau pendorongnya. Manajemen sumber daya manusia adalah segala potensi yang ada pada manusia baik berupa akal pikiran, tenaga, keterampilan yang dapat digunakan baik untuk dirinya sendiri maupun untuk organisasi atau perusahaan. Oleh karena itu, sumber daya manusia harus dikelola 


\section{Forum Bisnis Dan Kewirausahaan Jurnal Ilmiah STIE MDP}

dan dijaga dengan baik untuk meningkatkan efektivitas dan efisiensi organisasi atau perusahaan.

Manajemen yang baik dalam sebuah perusahaan ialah menempatkan orang yang tepat pada posisi yang tepat. Oleh sebab itu, perusahaan memiliki kualifikasi sumber daya manusia yang sesuai dengan sesuai kriteria perusahaan. Salah satu kualifikasi yang dibutuhkan oleh perusahaan yaitu disiplin kerja. Disiplin kerja adalah suatu sikap dan perilaku seseorang yang menunjukkan ketaatan, kepatuhan, kesetiaan, keteraturan dan ketertiban pada peraturan perusahaan atau organisasi dan normanorma sosial yang berlaku. meningkatkan kinerja karyawan tersebut.

Salah satu faktor yang mempengaruhi kinerja adalah disiplin kerja. Setiap perusahaan selalu mengharapkan karyawannya mempunyai disiplin yang tinggi terhadap perusahaan. Sebab, kedisiplinan berisikan peraturan-peraturan yang diberikan oleh perusahaan untuk ditaati dan dijakankan oleh karyawan. Dengan kedisiplinan diharapkan dapat membuat pekerjaan seefisien mungkin dan terpeliharanya tata tertib perusahaan, serta karyawan dapat menjalankan tugasnya dengan penuh kesadaran serta dapat mengembangkan tenaga dan pikirannya semaskimal mungkin demi terwujudnya tujuan perusahaan.

\subsection{Perumusan Masalah}

Berdasarkan hal tersebut penulis merumuskan masalah dalam penelitian ini yaitu "Apakah disiplin kerja berpengaruh baik secara parsial maupun simultan terhadap kinerja karyawan PT Minanga Ogan Kabupaten Ogan Komering Ulu?"

\section{Landasan Teori}

\subsection{Manajemen Sumber Daya Manusia}

Manajemen sumber daya manusia merupakan bagian dari ilmu manajemen yang memfokuskan perhatiannya pada pengaturan peranan sumber daya manusia dalam kegiatan suatu organisasi.
Manajemen sumber daya manusia (human resources management) berbeda dengan manajemen personalia (personnel management). Menurut Sule dan Saefullah (2009:13) manajemen sumber daya manusia adalah penerapan manajemen berdasarkan fungsinya untuk memperoleh sumber daya manusia yang terbaik bagi bisnis yang kita jalankan dan bagaimana sumber daya manusia yang terbaik tersebut dapat dipelihara dan tetap bekerja bersama kita dengan kualitas pekerjaan yang senantiasa konstan ataupun bertambah.

Sudaryono (2015: 121), sumber daya manusia adalah ilmu dan seni yang mengatur hubungan dan peran tenaga kerja agar efisien dan efektif sehingga tercapai tujuan bersama perusahaan, karyawan dan masyarakat.

Dari pengertian diatas dapat disimpulkan bahwa manajemen sumber daya manusia adalah pengelolaan individu-individu yang bekerja dalam organisasi yang berupa hubungan antara pekerjaan dengan pekerjaan, terutama untuk menciptakan pemanfaatan individu-individu secara produktif sebagai usaha mencapai tujuan organisasi dan dalam rangka perwujudan kepuasan kebutuhan individuindiviu tersebut.

\subsection{Disiplin Kerja}

Alma (2012:203) mengatakan bahwa disiplin kerja dapat diartikan sebagai suatu sikap patuh, sikap, tingkah laku, dan perbuatan yang sesuai dengan peraturan perusahaan baik yang tertulis maupun tidak. Penegakan disiplin tidak dapat dilakukan seketika, tapi harus dilatih dan diawasi sejak dini dan rutin. Karyawan dilatih dan diberi sangsi dari yang ringan sampai hukuman berat. Dan yang terpenting karyawan diikut sertakan merumuskan aturan-aturan disiplin tersebut, agar dipatuhi bersama.

Menurut Ariko (Stoner 2012:309), disiplin kerja adalah kesadaran dan kesediaan seseorang menaati semua peraturan perusahaan atau organisasi dan norma-norma sosial yang berlaku. Adapun indikator disiplin kerja menurut Ariko (Mathis, 2013:236) yaitu sebagai berikut: 


\section{Forum Bisnis Dan Kewirausahaan \\ Jurnal Ilmiah STIE MDP}

1. Absensi yaitu pendataan kehadiran karyawan yang sekaligus merupakan alat untuk melihat sejauhmana karyawan mematuhi peraturan yang berlaku dalam perusahaan.

2. Sikap dan perilaku yaitu tingkat penyesuaian diri seorang karyawan dalam melaksanakan tugas atasannya.

3. Tanggung jawab yaitu hasil kerja karyawan atas pekerjaan yang diserahkan kepadanya.

\subsection{Kinerja Karyawan}

Kinerja karyawan adalah tingkat di mana karyawan mencapai persyaratan-persyaratan pekerjaan. Adapun manfaat dari penilaian kinerja karyawan (Sumarni dan Soeprihanto, 2010:376) yaitu sebagai berikut:

1. Memberi informasi yang dapat membantu di dalam keputusan-keputusan yang berkaitan dengan masalah promosi, kenaikan gaji, transfer maupun pemberhentian tenaga kerja.

2. Dapat digunakan untuk mendorong pengembangan karyawan.

Menurut Kasmir (2019:181) kinerja adalah hasil kerja dan perilaku kerja yang telah dicapai dalam menyelesaikan tugas-tugas dan tanggung jawab yang diberikan dalam suatu periode tertentu. Kemudian kinerja dapat di ukur dari kemampuannya menyelesaikan tugas-tugas dan tanggung jawab yang diberikan. Artinya dalam kinerja mengandung unsur standar pencapaian yang harus dipenuhi.

Adapn faktor-faktor yang mempengaruhi kinerja adalah sebagai berikut:

1. Kemampuan dan keahlian yang dimiliki seseorang dalam melakukan suatu pekerjaan

2. Pengetahuan tentang pekerjaan

3. Rancangan pekerjaan yang akan memudahkan karyawan dalam mencapai tujuannya
4. Kepribadian yang dimiliki seseorang

5. Motivasi kerja merupakan dorongan bagi seseorang untuk melakukan pekerjaan

6. Kepemimpinan dan gaya kepemimpinan dalam menghadapi atau memerintah bawahannya

7. Budaya organisasi merupakan kebiasaankebiasaan atau norma-norma yang berlaku dan dimiliki oleh suatu organisasi atau perusahaan

8. Kepuasan kerja seseorang sebelum dan setelah melakukan suatu pekerjaan

9. Lingkungan kerjanmerupaka kondisi di sekitar lokasi tempat kerja

10.Loyalitas merupakan kesetiaan karyawan untuk tetap bekerja dan membela perusahaan di mana tempatnya bekerja

11. Komitmen merupakan kepatuhan karyawan untuk menjalankan kebijakan atau peraturam perusahaan dalam bekerja

12.Disiplin kerja merupakan usaha karyawan untuk menjalankan aktivitas kerjanya secara sungguhsungguh

\subsection{Pengaruh Disiplin Kerja Terhadap Kinerja Karyawan}

Penilaian kinerja penting artinya bukan hanya untuk kepentingan perusahaan semata, akan tetapi juga untuk kepentingan karyawan itu sendiri. Bagi perusahaan, penilaian kinerja karyawan secara keseluruhan dapat dilihat dari jumlah laba yang akan diperoleh dalam suatu periode. Sedangkan bagi karyawan, kegunaan penilaian kinerja adalah untuk mengukur kemampuannya untuk melakukan suatu pekerjaan, sekaligus sebagai koreksi atas hasil pekerjaannya.

Menurut Kasmir (2019:193), disiplin kerja merupakan usaha untuk menjalankan aktivitas kerjanya secara sungguh-sungguh. Disiplin kerja 
dalam hal ini dapat berupa waktu, misalnya masuk kerja selalu tepat waktu. Kemudian disiplin dalam mengerjakan apa yang diperintahkan kepadanya sesuai dengan perintah yang harus dikerjakan. Karyawan disiplin akan mempengaruhi kinerja.

\subsection{Kerangka Pemikiran}

Keberhasilan suatu organisasi dipengaruhi

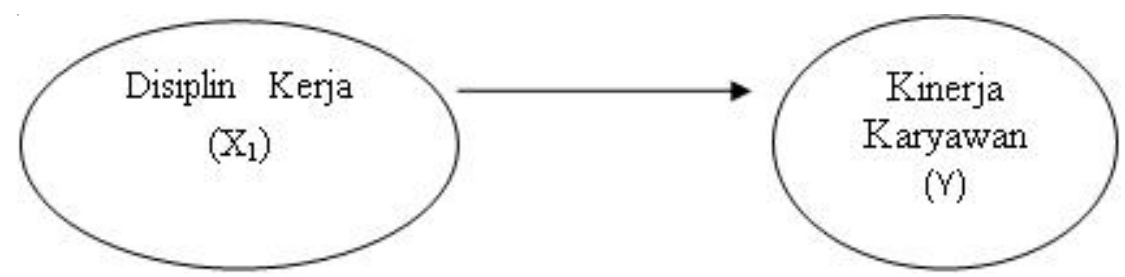

Gambar 1. Kerangka Pemikiran

\section{Metodologi Penelitian}

\subsection{Ruang Lingkup Penelitian}

Penelitian ini dilakukan pada karyawan PT Minanga Ogan Kabupaten Ogan Komering Ulu. Variabel yang diteliti yaitu disiplin kerja dan kinerja.

\subsection{Data dan Sumber Data}

Data yang digunakan dalam penelitian ini menggunakan data Primer (Primary Data). Data primer adalah data yang diperoleh langsung dari sumber data yang dikumpulkan dari hasil pengisian kuesioner (Sugiyono, 2014: 193).

\subsection{Populasi dan Sampel Penelitian}

Populasi yaitu apabila seseorang ingin meneliti semua elemen yang ada dalam wilayah penelitian, maka penelitiannya merupakan penelitian populasi (Arikunto, 2010: 102). Pada penelitian ini jumlah karyawan PT Minanga Ogan Kabupaten Ogan Komering Ulu sebanyak 89 orang, jumlah ini diperoleh berdasarkan hasil observasi langsung.

\subsection{Model Analisis}

oleh kinerja karyawan dalam melaksanakan tugas sesuai dengan tanggung jawab yang diberikan kepadanya dan memiliki kedisiplinan dalam bekerja. Dalam variabel kerangka pemikiran berdasarkan penjelasan di atas terdapat anak panah yang menunjukkan pengaruh variabel bebas/ independen terhadap variabel terikat/ dependen. Kerangka pemikiran teoritis ditampilkan sebagai berikut:

\subsubsection{Analisis Data}

Penelitian ini yang akan dianalisis adalah tanggapan responden tentang pengaruh disiplin kerja terhadap kinerja karyawan PT Minanga Ogan Kabupaten Ogan Komering Ulu berdasarkan kuesioner atau angket yang telah disebar dengan menggunakan Skala Likert. Skala Likert merupakan skala yang berisi lima tingkatan jawaban mengenai kesetujuan responden terhadap statement/ pertanyaan yang dikemukakan melalui opsi yang tersedia. Yang diklasifikasikan sebagai berikut.

a) SS : Sangat setuju

b) $S$ : Setuju

c) RR : Ragu-ragu

d) TS :Tidak setuju

e) STS : Sangat Tidak Setuju

\subsubsection{Uji Validitas dan Reliabilitas}

\section{Uji Validitas}

Menurut Riduwan dan Sunarto (2010:348), uji validitas digunakan untuk menunnukkan tingkat kevalidan suatu instrument. Dalam penelitian ini, uji validitas dilakukan dengan menggunakan metode Corrected Item-Total Correlation. Kriteria pengambilan keputusan sebagai berikut: 
a. Jika $r_{\text {hitung }}>r_{\text {tabel }}$ maka angket tersebut adalah valid

b. Jika $r_{\text {hitung }}<r_{\text {tabel }}$ maka angket tersebut adalah tidak valid

\section{Uji Reliabilitas}

Hasil uji reliabilitas menggunakan metode Cronbach Alph, reliabilitas kurang dari 0,6 adalah kurang baik, sedangkan 0,7 dapat diterima dan atas 0,8 adalah baik.

\subsection{Batasan Operasional}

Variabel penelitian ini secara umum dibagi menjadi dua, yaitu variabel independen dan variabel dependen. Variabel dependen adalah disiplin kerja $\left(\mathrm{X}_{1}\right)$ dan variabel independen dalam penelitian ini adalah kinerja karyawan (Y).

\section{HASIL ANALISIS DAN PEMBAHASAN}

\subsection{Hasil Analisis}

\subsubsection{Analisis Regresi Linear Berganda}

Analisis regresi linier berganda dalam penelitian ini dilakukan dengan menggunakan bantuan program SPSS 20, dengan hasil sebagai berikut.

Tabel 1. Hasil Analisis Regresi Linier Berganda

\begin{tabular}{|c|l|r|r|r|r|r|}
\hline \multirow{2}{*}{ Model } & \multicolumn{2}{|c|}{$\begin{array}{c}\text { Unstandardized } \\
\text { Coefficients }\end{array}$} & $\begin{array}{c}\text { Standardized } \\
\text { Coefficients }\end{array}$ & \multirow{2}{*}{ t } & \multirow{2}{*}{ Sig. } \\
\cline { 2 - 6 } & B & $\begin{array}{c}\text { Std. } \\
\text { E rror }\end{array}$ & Beta & & \\
\hline \multirow{2}{*}{1} & (Constant) & .462 & .870 & & .530 & .597 \\
\cline { 2 - 7 } & Disiplin Kerja & .679 & .056 & .675 & 12.189 & .000 \\
\hline
\end{tabular}

Sumber: Data primer yang diolah, 2020

Berdasarkan dari hasil perhitungan analisis regresi linier berganda dengan bantuan program SPSS 20 dapat disusun persamaan regresi linier berganda sebagai berikut:

$\mathrm{Y}=0,462+0,679 \mathrm{X}_{1}+\mathrm{e}$

1. Nilai konstanta sebesar 0,462 menyatakan bahwa jika $X_{1}$ (Disiplin Kerja) tidak ada maka Y (Kinerja Karyawan) sebesar nilai konstanta yaitu 0,462.

2. Nilai koefisien regresi $X_{1}$ (Disiplin Kerja) sebesar 0,679 menyatakan bahwa setiap perubahan sebesar satu satuan $\mathrm{X}_{1}$ (Disiplin Kerja), maka $\mathrm{Y}$ (Kinerja Karyawan) juga naik sebesar 0,679.

\subsubsection{Pengujian Hipotesis Individual (Uji T)}

Uji t digunakan untuk mengetahui ada tidaknya hubungan atau pengaruh yang berarti (signifikan) antara variabel independen secara parsial terhadap variabel dependen (Sunyoto, 2011: 146).

Besarnya tingkat signifikan $(\alpha)$ yang digunakan dalam penelitian ini adalah $5 \%$ atau $\alpha=$ 0,05 , sedangkan besarnya nilai derajat kebebasan (df) dicari dengan rumus $n-k-1(89-2-1=86=1,988)$. Pengujian pengaruh masing-masing variabel bebas terhadap variabel terikat dapat dilihat pada tabel 2 berikut:

Tabel 2. Hasil T-test

\begin{tabular}{|c|l|r|r|r|r|r|}
\hline \multirow{2}{*}{ Model } & \multicolumn{2}{|c|}{$\begin{array}{c}\text { Unstandardized } \\
\text { Coefficients }\end{array}$} & $\begin{array}{c}\text { Standardized } \\
\text { Coefficients }\end{array}$ & \multirow{2}{*}{ t } & \multirow{2}{*}{ Sig. } \\
\cline { 2 - 7 } & \multicolumn{1}{|c|}{ B } & $\begin{array}{c}\text { Std. } \\
\text { Error }\end{array}$ & \multicolumn{2}{c|}{ Beta } & & \\
\hline \multirow{2}{*}{1} & (Constant) & .462 & .870 & & .530 & .597 \\
\cline { 2 - 7 } & Disiplin Kerja & .679 & .056 & .675 & 12.189 & .000 \\
\hline
\end{tabular}


Berdasarkan hasil pengolahan data yang terdapat pada tabel 4.1.2 diperoleh:

1. Koefisien t-hitung $X_{1}$ (Disiplin Kerja) sebesar 12,189 dengan t-tabel sebesar 1,988 maka $\mathrm{X}_{1}$
(Disiplin Kerja) secara signifikan berpengaruh terhadap Y (Kinerja Karyawan), karena t-hitung lebih besar dari pada t-tabel yaitu 12,189>1,988. Berdasarkan uraian di atas maka dapat dilihat pada gambar di bawah ini:

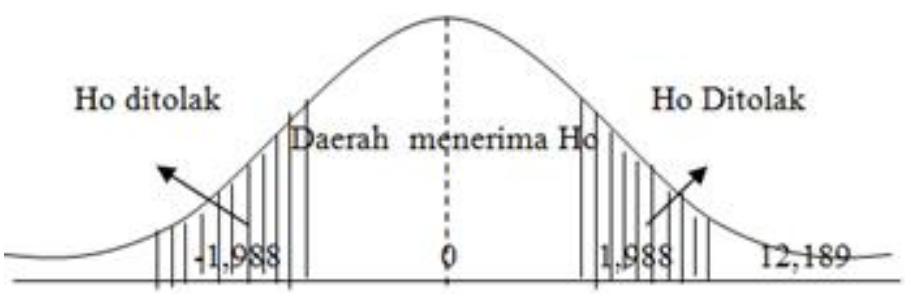

Gambar 2. Daerah Penerimaan Hipotesis Uji-t Variabel Disiplin Kerja (X1)

\subsubsection{Pengujian Hipotesis Serentak (Uji F)}

Uji F dilakukan untuk mengetahui pengaruh antara variabel independen terhadap variabel dependen secara bersama-sama (Priyatno, 2013: 48). Uji $F$ dalam penelitian ini menggunakan taraf signifikan $(\alpha)=5 \%$ dengan derajat kebebasan $(\mathrm{dk})$ $=(\mathrm{n}-\mathrm{k}=89-2-1=86=3,10)$. Pengambilan keputusan dilakukan dengan cara membandingkan nilai F-hitung dengan nilai F-tabel yaitu jika, F-hitung $>$ F-tabel artinya diantara variabel independent secara bersama-sama mempunyai pengaruh signifikan terhadap variabel dependen. Hasil perhitungan Uji F dapat dilihat pada tabel berikut:

Tabel 3. Hasil Pengujian Secara Bersama-sama

\begin{tabular}{|c|l|r|r|r|r|c|}
\hline \multicolumn{2}{|c|}{ Model } & $\begin{array}{c}\text { Sum of } \\
\text { Squares }\end{array}$ & \multicolumn{1}{c|}{ df } & $\begin{array}{c}\text { Mean } \\
\text { Square }\end{array}$ & F & Sig. \\
\hline \multirow{2}{*}{1} & Regression & 3864.281 & 2 & 1932.141 & 676.670 & $.000^{\circ}$ \\
\cline { 2 - 7 } & Residual & 245.562 & 86 & 2.855 & & \\
\cline { 2 - 7 } & Total & 4109.843 & 88 & & & \\
\hline
\end{tabular}

Sumber: Data primer yang diolah, 2020

Berdasarkan tabel di atas diperoleh koefisien nilai Fhitung 676,670 yang lebih besar dari nilai F-tabel sebesar 3,10 hal ini berarti $F_{\text {hitung }}>F_{\text {tabel }}$ sehingga dapat disimpulkan bahwa disiplin kerja berpengaruh secara simultan terhadap kinerja karyawan PT Minanga Ogan Kabupaten Ogan Komering Ulu.

\subsubsection{Analisis Koefisien Determinasi $\left(R^{2}\right)$}

Menurut Priyatno (2011:251) analisis koefisien determinasi digunakan untuk mengetahui persentase sumbangan pengaruh variabel independen secara simultan (bersama-sama) terhadap variabel dependen.

Hasil uji analisis koefisien determinasi disajikan pada tabel 4 berikut.

Tabel 4. Koefisien Determinasi $\left(\mathrm{R}^{2}\right)$

\begin{tabular}{|c|c|r|r|r|r|}
\hline Model & R & $\begin{array}{c}\text { R } \\
\text { Square }\end{array}$ & $\begin{array}{c}\text { Adjusted R } \\
\text { Square }\end{array}$ & $\begin{array}{c}\text { Std. Error of } \\
\text { the Estimate }\end{array}$ & $\begin{array}{c}\text { Durbin- } \\
\text { Watson }\end{array}$ \\
\hline 1 & $970^{3}$ & .940 & .939 & 1.68978 & 1.887 \\
\hline
\end{tabular}

Sumber: Data primer yang diolah, 2020 


\section{Forum Bisnis Dan Kewirausahaan Jurnal Ilmiah STIE MDP}

Berdasarkan tabel di atas diperoleh nilai $R$ Square sebesar 0,940 atau $(94,0 \%)$. Hal ini menunjukkan bahwa pengaruh disiplin kerja memberikan variasi terhadap variasi kinerja karyawan PT Minanga Ogan Kabupaten Ogan Komering Ulu sebesar 0,940 atau $(94,0 \%)$, sedangkan sisanya sebesar 6\% divariasikan atau dijelaskan oleh variabel lain yang tidak dimasukkan dalam model penelitian ini misalnya lingkungan kerja, motivasi kerja dan pengembangan karier.

\subsection{Pembahasan}

Berdasarkan hasil pengolahan data yang telah dilakukan diperoleh nilai koefisien t-hitung $\mathrm{X}_{1}$ (Disiplin Kerja) sebesar 12,189 dengan t-tabel sebesar 1,988 maka $X_{1}$ (Disiplin Kerja) secara signifikan berpengaruh terhadap Y (Kinerja Karyawan). Sementara itu, nilai F-hitung 676,670 yang lebih besar dari nilai F-tabel sebesar 3,10 hal ini berarti $\mathrm{F}_{\text {hitung }}>$ $\mathrm{F}_{\text {tabel }}$ sehingga dapat disimpulkan bahwa disiplin kerja berpengaruh secara simultan terhadap kinerja karyawan PT Minanga Ogan Kabupaten Ogan Komering Ulu. Dan, besar nilai $R$ Square sebesar 0,940 atau $(94,0 \%)$.

Hal ini menunjukkan bahwa pengaruh disiplin kerja terhadap kinerja karyawan PT Minanga Ogan Kabupaten Ogan Komering Ulu sebesar 0,940 atau $(94,0 \%)$, sedangkan sisanya sebesar $6 \%$ dipengaruhi atau dijelaskan oleh variabel lain yang tidak dimasukkan dalam model penelitian ini misalnya lingkungan kerja, motivasi kerja dan pengembangan karier.

\section{KESIMPULAN DAN SARAN}

\subsection{Kesimpulan}

Berdasarkan analisis dan pembahasan yang telah dilakukan, maka dapat ditarik kesimpulan bahwa:

1. Nilai koefisien t-hitung $X_{1}$ (Disiplin Kerja) sebesar 12,189 dengan t-tabel sebesar 1,988 maka $X_{1}$ (Disiplin Kerja) secara signifikan berpengaruh terhadap Y (Kinerja Karyawan), karena t-hitung lebih besar dari pada t-tabel.
2. Nilai F-hitung 676,670 yang lebih besar dari nilai F-tabel sebesar 3,10 hal ini berarti $F_{\text {hitung }}>F_{\text {tabel }}$ sehingga dapat disimpulkan bahwa Disiplin kerja berpengaruh secara simultan terhadap kinerja karyawan PT Minanga Ogan Kabupaten Ogan Komering Ulu.

3. Nilai $R$ Square sebesar 0,940 atau $(94,0 \%)$. Hal ini menunjukkan bahwa pengaruh disiplin kerja terhadap kinerja karyawan PT Minanga Ogan Kabupaten Ogan Komering Ulu sebesar 0,940 atau $(94,0 \%)$, sedangkan sisanya sebesar $6 \%$ dipengaruhi atau dijelaskan oleh variabel lain yang tidak dimasukkan dalam model penelitian ini misalnya lingkungan kerja, motivasi kerja dan pengembangan karier.

\subsection{Saran}

Berdasarkan hasil penelitian yang dilakukan oleh penulis maka penulis mempunyai saran kepada PT Minanga Ogan Kabupaten Ogan Komering Ulu agar dapat memahami lebih lanjut tentang pengaruh disiplin kerja yang di alami oleh pegawainya dengan cara memberikan sosialisasi pembinaan sikap kerja yang baik, dimana hal ini diharapkan dapat meningkatkan kinerja yang cepat.

\section{DAFTAR PUSTAKA}

[1] Arikunto, Suharsimi. 2010. Prosedur Penelitian Suatu Pendekatan Praktik. PT Rineka Cipta. Jakarta.

[2] Alma, Buchari. 2012. Pengantar Bisnis. Bandung: Alfabeta.

[3] Ariko, Meilinda Fitriani. 2018. Pengaruh Disiplin Kerja, Kompetensi, Serta Keselamatan Dan Kesehatan Kerja Terhadap Kinerja Karyawan PT. Sucofindo (Persero) Cabang Palembang. Jurnal Ilmu Manajemen. Volume 8 (1).

[4] Kasmir. 2019. Manajemen Sumber Daya Manusia. Rajawali Pers. Depok. 
[5] Mathis, R. L., dan Jackson, H.J. 2013. Manajemen Sumber Daya Manusia. Salemba Empat. Bandung

[6] Priyatno, Duwi. 2011. Analisis Statistik Data. MediaCom. Yogyakarta

[7] Riduwan. Sunarto. 2010. Pengantar Statistika. Alfabeta. Bandung

[8] Stoner, James A.F. 2012. Management. Jilid I (Edisi 6). Prehalindo. Jakarta

[9] Sudaryono. 2015. Pengantar Bisnis Teori dan Contoh Kasus. Andi Offset. Yogyakarta

[10] Sugiyono. 2014. Metode Penelitian Bisnis. Teori dan Contoh Kasus. Andi Offset. Yogyakarta.

[11] Sule, Ernie Tisnawati. dan Saefullah, Kurniawan. 2009. Pengantar Manajemen. Kencana. Jakarta

[12] Sumarni, Murti. Dan Soeprihanto, John. 2020. Pengantar Bisnis Dasar-Dasar Ekonomi Perusahaan. Liberty, Yogyakarta.

[13] Terry, George R. dan Rue, Leslie W. 2014. Dasar-dasar Manajemen. Bumi Aksara. Jakarta 